\title{
In vitro Fermentation Method as a Tool to Assess the Effects of Secondary Metabolites on Rumen Fermentation-A Brief Review
}

\author{
Helio Lima Neto ${ }^{1} \&$ Edward Okello ${ }^{2}$ \\ ${ }^{1}$ Olds College, Centre for Innovation, Technology Access Centre, Canada \\ ${ }^{2}$ Newcastle University, Institute of Neuroscience, UK \\ Correspondence: Helio Lima Neto, Olds College, Centre for Innovation, Technology Access Centre, 450050 St, \\ Olds, AB T4H 1R6, Canada. E-mail: hlima-neto@oldscollege.ca
}

\author{
Received: March 6, $2018 \quad$ Accepted: April 12, $2018 \quad$ Online Published: May 15, 2018 \\ doi:10.5539/jas.v10n6p28 URL: https://doi.org/10.5539/jas.v10n6p28
}

\begin{abstract}
In vitro fermentation is a useful method to test the effects of secondary metabolites on the rumen fermentation. It can be a noninvasive method when the rumen fluid is collected from slaughterhouses from dead animals. The experimental design for this type of experiment is normally a factorial design where common factors tested are: incubation time, main energy source incubated, and additive concentrations (secondary metabolites). The data gathered from the incubations can be quite extensive and therefore the statistical power of the in vitro method can be very good. In this paper we will discuss the main characteristics (how the method works and which parameters are measured) of the in vitro fermentation method.
\end{abstract}

Keywords: in vitro fermentation, ruminants, dairy cattle, beef cattle, sheep

\section{Introduction}

Noninvasive methods to study novel feedstuff to be used in animal agriculture have currently been developed and improved. The in vitro fermentation system can be a noninvasive method which allows laboratory testing of novel feedstuff produced secondary metabolites in the rumen. It is derived from the methodology developed by Tilley and Terry (1963), with some adjustments. For a noninvasive approach rumen fluid is pooled from different donors and taken to the laboratory to start the incubation. Once completed, the incubation will yield vast datasets with information such as: $\mathrm{pH}$, ammonia levels, methane concentration, volatile fatty acids, dry matter degradability, total gas production, profile of microbial population, amongst others (Calsamiglia et al., 2007; Makkar et al., 2006; Yang et al., 2010). The analysis of this information can reveal the effects of an individual chemical compound when incubated in the rumen.

\section{Rumen Digestive System and Considerations}

\subsection{Rumen Fermentation}

The rumen, which is about one-seventh of the body mass of ruminants (McDougall, 1948), is maintained at relatively constant temperature $\left(39^{\circ} \mathrm{C}\right)$, buffered by salivary secretion, and is an ideal fermentation site for microbial ecosystems. During fermentation of feedstuffs by microorganisms; VFA, microbial cells, NH3, carbon dioxide $\left(\mathrm{CO}_{2}\right), \mathrm{CH}_{4}$, adenosine triphosphate (ATP), and heat are formed. VFA and ATP are used as the available energy sources for the animal, while microbial cells are the significant source of quality protein entering the small intestine (Demeyer, 1981; Russel \& Hespell, 1981). Non-utilized NH3, CH4, and heat production may represent the loss of energy and $\mathrm{N}$ for the ruminants (Demeyer, 1981). In order to obtain appropriate knowledge and strategies to manipulate rumen fermentation, it is important to understand the mechanisms of carbohydrate and protein metabolism, methanogenesis, and acetogenesis in the rumen.

Ruminant diets contain substantial amounts of carbohydrate polymers such as cellulose, hemicellulose, starch, pectin, xylan, and water-soluble carbohydrates mainly in the form of fructans (McDonald et al., 2011; Russel \& Hespell, 1981). A description of the conversion of carbohydrate polymers to VFA in the rumen is provided: diets containing plant particles are attacked by microorganisms and carbohydrate polymers are then released from plant cell structural matrices. After this, the carbohydrate polymers are hydrolysed to simple sugars such as cellobiose, maltose, xylobiose, hexoses, and pentoses by extracellular microbial enzymes. Cellulose is catalyzed by $\beta-1,4$-glucosidases to cellobiose and further converted either to glucose or glucose-1-phosphate. Starch is 
initially hydrolyzed by amylases to maltose and iso-maltose, and then by maltose phosphorylases or 1,6-glucosidases to either glucose or glucose-1-phosphate. Fructans are degraded by enzymes involving 2,1 and 2,6 linkages to form fructose. This may be produced, together with glucose by the degradation of sucrose naturally present in plant materials. In hemicellulose, xylan is broken down by enzymes attacking the $\beta-1,4$ linkages to give pentoses as the major product, xylose, and uronic acids. Uronic acids are also produced from pectins, which are initially hydrolized to pectic acid and methanol by pectin esterase. The pectic acid is then converted by polygalacturonidases to galacturonic acids to further yield xylose. Xylose may also be obtained from hydrolysis of the xylans, which may be hugely available in forages (McDonald et al., 2011).

\subsection{In vitro Method}

The incubation method works as follows: about $1 \mathrm{~g}$ of ground energy source sample (for example: straw or hay or silage), plus the secondary metabolite under test in different inclusion levels according to experimental design, are put into $50-\mathrm{ml}$ polypropylene tubes and $40 \mathrm{ml}$ of the buffered inoculum $(32 \mathrm{ml}$ of buffer solution plus $8 \mathrm{ml}$ of filtered rumen fluid) dispensed into each tube, purged with $\mathrm{CO}_{2}$ to maintain anaerobic conditions, sealed with rubber stoppers fitted with gas pressure release valves, and incubated in a temperature controlled shaking water bath $\left(39^{\circ} \mathrm{C}\right.$ ) (Figure 1). During incubations, each tube is manually mixed for few seconds, three times a day (morning, afternoon, and night). The fermentation modules are then collected at specific times according to experimental design (for example: $24 \mathrm{~h}$ and $72 \mathrm{~h}$ ) from the water bath and placed into an ice box (-10 $\left.{ }^{\circ} \mathrm{C}\right)$ to stop further fermentation. After that, the liquids and residues are separated by centrifuging each tube at $2500 \mathrm{rpm}$ for $10 \mathrm{~min}$. The supernatant of each tube is then collected to determine VFA concentrations while residues are dried for IVDMD determinations. A separate $2 \mathrm{ml}$ sample of each supernatant is also pipetted into a capped-container and mixed with $0.5 \mathrm{ml}$ of deproteinising solution containing $10 \mathrm{mmol} / \mathrm{L}$ of crotonic internal standard solution for VFA determination added and kept in a freezer $\left(-20^{\circ} \mathrm{C}\right)$. The fermentation modules can have pipes attached to them that will allow the harvest of the fermentation gases in $50 \mathrm{ml}$ glass syringes. Gas chromatography analysis methodology for methane and volatile fatty acid will be discussed in another publication.

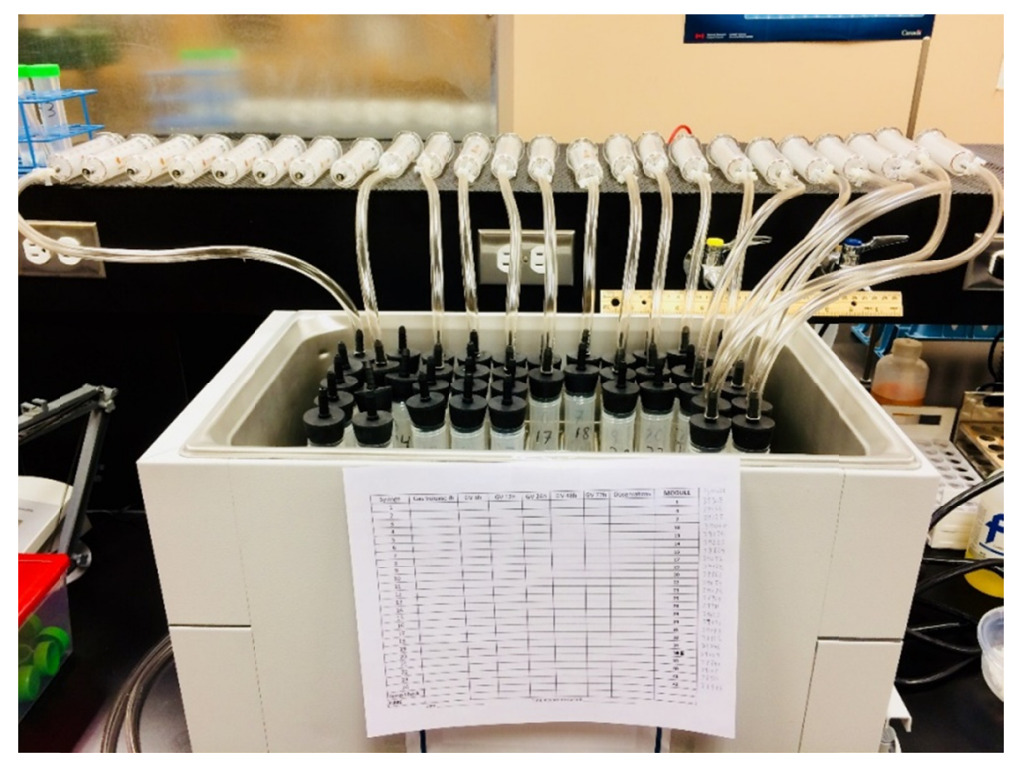

Figure 1. Shaking water bath with the fermentation modules and the harvesting pipes connected to the syringes to collect the fermentation gases

\subsection{Plant Extracts (Secondary Metabolites) and the Ruminal Fermentation}

Plant extracts containing secondary metabolites (e.g. saponins, solanine, solasodine, tannins, essential oils) are of increasing interest as alternative feed additives for humans because of their chemical properties and for ruminants because they can potentially inhibit rumen ciliate protozoa. Defaunation often lowers rumen methanogenesis because about 9 to $25 \%$ of ruminal methanogens live in association with protozoa (Newbold et al., 2008). Therefore, reducing methanogenesis is beneficial from the point of view that it can increase energy efficiency of the ruminant (Alexander et al., 2008) and from the reduction in the impact it can have towards the 
environment (Makkar \& Vercoe, 2007). These groups of natural "growth promoters" constitute a good opportunity to help farmers to increase animal production. Also the consumer can benefit because of the reduction of the potential transmittance of resistance or harmful effects caused by traditional antibiotics, which are an alternative. Practical effects of supplementing these chemicals are described in the literature ranging from metabolic effects which optimize rumen fermentation through to changes in milk composition.

Table 1. Some of the potential effects of secondary metabolites from plants found in the literature

\begin{tabular}{ll}
\hline Described Effect & Author \\
\hline Increased digestibility of feedstuffs & Yang et al., 2007 \\
pH stabilizing effect & Benchaar et al., 2006 \\
Potential to manipulate milk fatty acid content & Benchaar \& Chouinard, 2009 \\
Increased propionate production & Poungchompua et al., 2009 \\
Increased nitrogen retention & Wanapat et al., 2008 \\
Increased efficiency in converting food to milk & Lovett et al., 2006 \\
Increased milk yield and lactose content & Benchaar et al., 2007 \\
In vivo and in vitro reduction of methane production & Wang et al., 2009 \\
Increased microbial protein synthesis & Makkar et al., 2006 \\
Reduced protein and energy losses & Calsamiglia et al., 2007 \\
Increased feed intake & Yang et al., 2010 \\
Enhanced acetate/propionate ratio in the rumen & Benchaar \& Chouinard, 2009 \\
Milk composition with beneficial properties which have potential & Parodi, 1999 \\
anticarcinogenic agents (isoprenoids from plants) & \\
\hline
\end{tabular}

\subsection{The Utilization of the in vitro Fermentation Method and Some Literature Findings}

Alexander et al. (2008) completed an in vitro study to identify plant extracts that modulate partitioning of degraded organic matter (OM) towards microbial protein synthesis, at the expense of gas production, and decrease protein degradation in the rumen. They found that that aqueous methanol extract of $M$. oleifera seed and aqueous extract of $P$. kurroa root may have potential as feed additives to increase the efficiency of utilization of energy and nitrogen in ruminant diets. In addition, a review of the potential of some chemicals to manipulate rumen fermentation, utilizing publications that used in vitro fermentation method, have indicated that garlic oil, cinnamaldehyde (the main active component of cinnamon oil), eugenol (the main active component of the clove bud), capsaicin (the active component of hot peppers), and anise oil, among others, may increase propionate production, reduce acetate or methane production, and modify proteolysis, peptidolysis, or deamination in the rumen (Calsamiglia et al., 2007).

Another work utilizing the in vitro fermentation method, found that a substantial amount (71-93\%) of tannins soluble in aqueous acetone was released from leaves of some trees and shrubs on incubation in the in vitro medium for $48 \mathrm{~h}$. It also concluded that he rumen liquor was not capable of degrading oligomeric condensed tannins (Makkar et al., 2006). Newbold et al. (1995) studied the importance of methanogenic bacteria associated with ciliate protozoa either by removing protozoa from whole rumen fluid (using defaunated rumen fluid to correct for the effects of centrifugation on bacteria) or by isolating the protozoa. Rumen fluid was withdrawn from sheep inoculated with either Polyplastron multivesiculatum, a co-culture of Isotricha prostoma plus Entodinium spp. or a mixed type B fauna of Entodinium, Eudiplodinium and Epidinium spp. They found that methanogenesis was highest in rumen fluid containing a mixed protozoal population of the following genera: Entodinium, Eudiplodinium and Epidinium, was lower in defaunated rumen fluid and lowest in rumen fluid containing either I. prostoma plus Entodinium or P. multivesiculatum. Also, methanogenic bacteria associated with rumen ciliates were apparently responsible for between 9 and $25 \%$ of methanogenesis in rumen fluid.

Lima Neto (2012) investigated the effects of plant fractions (Solanum lycocarpum St. Hil.) on the rumen fermentation utilizing the in vitro fermentation system. The leaf fraction of the shrub (10 g/Kg DM inclusion) had the strongest effect when added to the Lucerne and increased ruminal the Acetate: Propionate $(\mathrm{P}<0.05)$. The author also found that when SL fractions were evaluated with incubated ryegrass hay, root and stem fractions decreased Ace: Prop $(\mathrm{P}<0.05)$. 


\section{Conclusions}

The in vitro fermentation method is a powerful tool to study secondary metabolites in the rumen ecosystem. The method can generate a vast quantity of data, and the results can be validated with a subsequent in vivo trial, where similar treatments are tested. Secondary metabolites can definitely be useful to manipulate rumen fermentation and future studies will shed some light on the best ways to utilize them.

\section{References}

Alexander, G., Singh, B., Sahoo, A., \& Bhat, T. K. (2008). In vitro screening of plant extracts to enhance the efficiency of utilization of energy and nitrogen in ruminant diets. Animal Feed Science and Technology, 145, 229- 244. https://doi.org/10.1016/j.anifeedsci.2007.05.036

Benchaar, C., \& Chouinard, P. Y. (2009). Short communication: Assessment of the potential of cinnamaldehyde, condensed tannins, and saponins to modify milk fatty acid composition of dairy cows. Journal of Dairy Science, 92, 3392-3396. https://doi.org/10.3168/jds.2009-2111

Benchaar, C., Petit, H. V., Berthiaume, R., Ouellet, D. R., Chiquette, J., \& Chouinard, P. Y. (2007). Effects of essential oils on digestion, ruminal fermentation, rumen microbial populations, milk production, and milk composition in dairy cows fed alfalfa silage or corn silage. Journal of Dairy Science, 90, 886-897. https://doi.org/10.3168/jds.S0022-0302(07)71572-2

Benchaar, C., Petit, H. V., Berthiaume, R., Whyte, T. D., \& Chouinard, P. Y. (2006). Effects of addition of essential oils and monensin premix on digestion, ruminal fermentation, milk production, and Milk Composition in Dairy Cows. Journal of Dairy Science, 89, 4352-4364. https://doi.org/10.3168/jds.S00220302(06)72482-1

Calsamiglia, S., Busquet, M., Cardozo, P. W., Castillejos, L., \& Ferret, A. (2007). Invited review: Essential oils as modifiers of rumen microbial fermentation. Journal of Dairy Science, 90, 2580-2595. https://doi.org/ $10.3168 /$ jds.2006-644

Demeyer, D. I. (1981). Rumen microbes and digestion of plant cell walls. Agriculture and Environment, 6(2-3), 295-337. https://doi.org/10.1016/0304-1131(81)90020-5

Lima Neto, H. R. (2012). Effects of Solanum lycocarpum St. Hil. on the rumen fermentation (PhD Thesis, Newcastle University, United Kingdom).

Lovett, D. K., Stack, L., Lovell, S., Callan, J., Flynn, B., Hawkins, M., \& O’Mara, F. P. (2006). Effect of feeding Yucca schidigera extract on performance of lactating dairy cows and ruminal fermentation parameters in steers. Livestock Science, 102, 23-32. https://doi.org/10.1016/j.livsci.2005.11.005

Makkar, H. P. S., \& Vercoe, P. E. (2007). Measuring methane production from ruminants. Springer Verlag. https://doi.org/10.1016/j.tibtech.2015.10.004

Makkar, H. P. S., Blümmel, M., \& Becker, K. (2006). In vitro effects of and interactions between tannins and saponins and fate of tannins in the rumen. Journal of the Science of Food and Agriculture, 69, 481-493. https://doi.org/10.1002/jsfa.2740690413

McDonald, P., Edwards, R. A., Greenhalgh, J. F. D., Morgan, C. A., Sinclair, L. A., \& Wilkinson, R. G. (2011). Animal Nutrition (7th ed.). Pearson Education Ltd., UK.

McDougall, E. I. (1948). Studies on ruminant saliva: The composition and output of sheep's saliva. Biochemical Journal, 43(1), 99-100. https://doi.org/10.1042/bj0430099

Newbold, C. J., Lassalas, B., \& Jouany, J. P. (2008). The importance of methanogens associated with ciliate protozoa in ruminal methane production in vitro. Letters in Applied Microbiology, 21, 230-234. https://doi.org/10.1111/j.1472-765X.1995.tb01048.x

Parodi, P. W. (1999). Conjugated linoleic acid and other anticarcinogenic agents of bovine milk fat. Journal of Dairy Science, 82, 1339-1349. https://doi.org/10.3168/jds.S0022-0302(99)75358-0

Poungchompua, O., Wanapat, M., Wachirapakornb, C., Wanapat, S., \& Cherdthong, A. (2009). Manipulation of ruminal fermentation and methane production by dietary saponins and tannins from mangosteen peel and soapberry fruit. Archives of Animal Nutrition, 63, 389-400. https://doi.org/10.1080/17450390903020406

Russel, J. B., \& Hespell, R. B. (1981). Microbial rumen fermentation. Journal of Dairy Science, 64(6), 1153-1169. https://doi.org/10.3168/jds.S0022-0302(81)82694-X 
Tilley, J. M. A., \& Terry, R. A. (1963). A Two-Stage Technique for the in vitro Digestion of Forage Crops. Journal of British Grassland Society, 18, 104-111. https://doi.org/10.1111/j.1365-494.1963.tb00335

Wanapat, M., Khejornsart, P., Pakdee, P., \& Wanapat, S. (2008). Effect of supplementation of garlic powder on rumen ecology and digestibility of nutrients in ruminants. Journal of the Science of Food and Agriculture, 88, 2231-2237. https://doi.org/10.1002/jsfa.3333

Wang, C. J., Wang, S. P., \& Zhou, H. (2009). Influences of flavomycin, ropadiar, and saponin on nutrient digestibility, rumen fermentation, and methane emission from sheep. Animal Feed Science and Technology, 148, 157-166. https://doi.org/10.1016/j.anifeedsci.2008.03.008

Yang, W. Z., Ametaj, B. N., Benchaar, C., He, M. L., \& Beauchemin, K. A. (2010). Cinnamaldehyde in feedlot cattle diets: Intake, growth performance, carcass characteristics, and blood metabolites. Journal of Animal Science, 88, 1082. https://doi.org/10.2527/jas.2008-1608

Yang, W. Z., Benchaar, C., Ametaj, B. N., Chaves, A. V., He, M. L., \& McAllister, T. A. (2007). Effects of garlic and juniper berry essential oils on ruminal fermentation and on the site and extent of digestion in lactating cows. Journal of Dairy Science, 90, 5671. https://doi.org/10.3168/jds.2007-0369

\section{Copyrights}

Copyright for this article is retained by the author(s), with first publication rights granted to the journal.

This is an open-access article distributed under the terms and conditions of the Creative Commons Attribution license (http://creativecommons.org/licenses/by/4.0/). 